\title{
US-CHINA COMPLEXITY: DEFINING THE POST-COVID-19 PANDEMIC WORLD
}

\author{
Iulian Chifu ${ }^{1}$ \\ "Carol I" National Defence University
}

\begin{abstract}
The US-China relation becomes the most important part of the international new postpandemic order related to the evolution of the world order after the Covid-19. We are talking about the most important economies of the world, giving $25 \%$ and $23.5 \%$ of the world GDP, economies and countries involved in a number of strategic rivalries as well as of harsh competitions, with a lot of newly come instruments that do not benefit of any international regime, rules and norms - cyber, a.i., quantum computers, space, Arctic region etc. In the absence of a dominant power able to impose the respect of a rules based world and to project its power in order to forge the new rules and norms in the field of new technologies, the US needs a real multilateralism and a conjunction of the democratic powers in order to acquire altogether the needed preeminence in order to get those rules and norms approved at the level of global institutions, if it is not for a smooth bilateral relation with China which could agree a number of such provisions and try to negotiate for including its own interest.
\end{abstract}

Keywords: global volatility; strategic rivalry; primacy of competition; power balancing; assuming risks; frictions; conflict; confrontation.

\section{GLOBAL VOLATILITY: G2 VERSUS TRADING INSULTS}

The relationship between China and the US is not at its high, on the contrary: there was never a more vivid and public miss acceptance between the two countries except for the economic war and the pandemic period when president Donald Trump embraced the concept of "Chinese virus" (Khan 2020) for the Covid-19 pandemic to underline the link to Wuhan, China. Moreover, at some moments, he put the blame on the P4 laboratory in Wuhan for producing the virus (Coronavirus: Trump stands by China lab origin theory for virus 2020), even though there were no evidence in this direction. That and the economic war were definitory for the worse bilateral relations between China and the US in history.

It is true, on another notice, that China itself changed dramatically its behaviour during the pandemic crisis. Pressed by perceived responsibility and even the perspective of being sued for compensation due to the fact that it didn't notified the world in due time about the coronavirus, it didn't contain the virus itself in Wuhan and not allow it to spread as pandemic in the whole world, and that it was ultimately responsible for the pandemic in the world (Miller and Strashak 2021), China moved to clear and unprecedented actions that costed a lot: first, it left its responsible and reasonable course of using propaganda and informational warfare, with its need for respectability (Vilmer and Charon 2020) that was its point and begin to use direct and harsh propaganda via Russia's networks in the West, European countries and the US, and Iranian ones for the Arab countries (Wiskeyman and Berger 2021). The main target was to avoid responsibility and try to alternate the source of the virus via conspiracy theories and fake news involving the virus being brought to China by American military athletes (Shumei and Lin 2020) or the virus being spread in Italy (Hui and Yusha and Juechenng 2021) or somewhere else way before the outbreak of the pandemic in Wuhan.

Second, China begins its unrealistic and costly campaign of the mask diplomacy(Jacinto 2021) involving the humanitarian help all over the world in spite of the law quality of its products -

\footnotetext{
${ }^{1}$ Corresponding author: Iulian.chifu@cpc-ew.ro
} 
criticised and returned from France, Italy, Spain, Slovakia - and mixing paid furnitures with humanitarian help. Then, in some cases, it begin to use its concentration of the manufactured products, needed at the same by all the states - be it masks, ventilators, antibiotics, protection material - for political conditioning for the prioritisation in supplies (Mattis and Auslin and Felter 2020). And in the third place, it revealed in some other cases that it used its dumping procedures and subventions from the state in order to take as much as possible from the supply chain in quite all products, producing smaller or bigger parts in China itself. In a period with huge problems in transportation due to quarantines and lockdowns, that situation revealed important gaps in the world trade and competition (Is it possible to end China's control of the global supply chain? 2020).

That behaviour made the US begin a process of repatriation of the companies (Pamuk and Shalal 2020),Japan investing money to relocation (Japan's game plan - to pay companies to move out of China 2020), as well as South Korea investing in repatriation, and made the EU, for instance, through the voice of the High Representative Josep Borrell (Terrabianca 2020; Small 2020), propose a change of behaviour - beside repatriation of highly sensitive technological products - and move manufactured goods needed in times of crisis in Northern Africa, with the aim of having them closer, of accessing easier and stabilizing a sustainable development as well as jobs for the migrants from the region moving to the EU. Security costs should be assumed and added to the strictly pragmatic and competitive market economy that lead to the concentration of the production of needed goods in China.

Therefore, three were the options of the US-China relations (Chifu 2020, 11-21)after the change of the American administration: a cooperation between the US and China in a type of G2, assuming the responsibilities for all the issues of the world - an approach strongly rejected by China which didn't want to assume anything more than its own security interests and sovereignty core territorial claims; an anarchic world, the G0 World of lan Bremmer (Bremmer 2012), where each side will use and abuse existing rules and ignore any type of new norms that would need to be put in place; and a confrontation between the US and China, with different type of instruments, that somebody will say is already on the way for some time. Fact is that the global volatility of the world during the Covid-19 pandemic was accentuated by the premises of a possible confrontation and conflict between the major economies of the world.

But the final conclusions were postponed until the new American administration took over and a more elaborate and long term approach to China is established by the new policies. And the conclusions came up with less inclination for a form of cooperation and a lot of insults traded by each side (Collinson 2021), as shown in the opening of the first meeting in Anchorage, March 18 (Biden Jr. 2021).

\section{THREE TRACK APPROACHES: HOW TO MANAGE STRATEGIC RIVALRY}

Before Anchorage, the new Biden administration has build up its China interim policy and assessment, and the conclusions after taking over the administration already prepared the way it envisaged to cope with the strategic rivalry assumed with China. First, it was the statement made by President Joe Biden (Joseph R. Biden Jr., 2021-1) at the State Department, on February the $4^{\text {th }}$, when installing formally State Secretary Anthony Blinken. It was both an approach with a liberal and idealistic instrument of defending democracy in front of authoritarianism when he stated: "American leadership must meet this new moment of advancing authoritarianism, including the growing ambitions of China to rival the United States and the determination of Russia to damage and disrupt our democracy" (Biden Jr. 2021-1).

More direct, regarding China, it has been defined as the most serious competitor for the US due to direct challenges posed to American and Western prosperity, security, and democratic values (Chifu 2021-1; Biden Jr. 2021). And the conclusion was also very clearly stated: "We'll confront China's economic abuses; counter its aggressive, coercive action; to push back on China's attack on human rights, intellectual property, and global governance. But we are ready to work with Beijing when it's in America's interest to do so. We will compete from a position of strength (...) renewing our 
role in international institutions, and reclaiming our credibility and moral authority, much of which has been lost" (Chifu 2021-1; Biden Jr. 2021-1).

So President Biden announced that the US will manage the strategic rivalry with China based on an approach with three tracks: cooperation, when the American interest is present, on major global issues; competition from a position of strength, through real multilateralism and engaging to sum up and converge all the resources of the democratic countries in the world to get the preeminent strategic weight necessary (Chifu 2021-1); and conflict and confrontation when defending its own principles and values. All those should be used in a framework defined as leading with diplomacy but being prepare to use defence and deterrence in order to block any attempt of Beijing to use force against allies and global partners. This three track approach is a more realistic and sophisticated one than the Cold War type approach of friends and foes and that's why old cliches do not match today, in the highly technological world of post-Covid-19 New World Order.

These premisses have been underlined by State Secretary Anthony Blinken on the $3^{\text {rd }}$ of March presentation of the Foreign Affairs Strategy of the US (Secretary of State Antony Blinken Speech on Foreign Policy 2021) in the wake of the launch of the Interim National Security Strategic Guidelines (Biden Jr. 2021-2) document launched in the same afternoon. In the elaborated statement of Mr. Blinken, the approach to China was far more present and defined. Russia and China were named, this time, "adversaries and competitors" which attack and raised doubts about the strength of the democracy and the democratic system. For the US, China became "the biggest geopolitical test of the 21st century", with a special point in the eight first priorities of the American Foreign policy (Chifu 2021-2).

"China is the only country with the economic, diplomatic, military and technological power, to seriously challenge the stable and open international system. All the rules, values and relationships that make the world work the way we want it to because it ultimately serves the interests and reflects the values of the American people. Our relationship with China will be competitive when it should, be collaborative when it can be and adversarial when it must be. The common denominator is the need to engage China from a position of strength. That requires working with allies and partners, not denigrating them because our combined weight is much harder for China to ignore" (Secretary of State Antony Blinken Speech on Foreign Policy 2021).

Actually, Anthony Blinken changed, by nuancing, the cooperation-competition-conflict triad confront, counter, push back for the confrontational part -with a relation defined as collaborative, competitive and adversarial at the same time, for each of the three tracks. It involved also the need for combined weight of allies and partners, and added "engaging in diplomacy and in international organizations", "standing up for our values when human rights are abused in Xinjiang or when democracy is trampled in Hong Kong because if we don't, China will act with even greater impunity" and "insisting on a level playing field" as a set up for a free and fair competition for everyone "pushing back against unfair trading practices by China and others".

If the success of managing the strategic rivalry with China sits on the diplomacy and transatlantic relations with the Europeans and the relations with the QUAD (Chifu 2021-3), the Quadrenial Partnership for Security between the US, India, Japan and Australia, plus the cooperation with the Global Partners - a format that has been already put in place in the NATO framework Wales Summit, 2014, via participation in the common effort in Afghanistan - let's see also how the EU-US relationship has been seen on the other part of the shores of the Atlantic. The details comes from the official statements of the White House (Readout of President Joseph R. Biden, Jr. Call with European Commission President Ursula von der Leyen 2021) and President of the European Commission, Ursula von der Leyen after the phone conversation Biden-von der Leyen on March the $5^{\text {th }}$ (Statement by President von der Leyen following her phone call with President of the United States, Joe Biden 2021). The White House Readout was more expeditive, including China as a main issue for "coordination and shared interest".

In the statement of Mrs von der Leyen, the reference to China was not present. In the more detailed press conference, that included the questions and answers, president Von der Leyen "defended the EU's recent investment pact with China as part of its economic partnership and 
competition with Beijing but said that, like Washington, Brussels saw China as a "systemic rival" when it came to democracy and human rights" (Chifu 2021-4). So, in qualifying the relationship with China, both the US and the EU had the same concept in hand - the"systemic rival". But in another part related to common enemies, she included Covid-19 and added that EU and the US should cooperate better to face the rising power of China: "Von der Leyen said she invited Biden to a global health summit in Rome on May 21 to streamline the fight against COVID-19, the common enemy that has killed over a million people in the EU and US combined. She hopes the commonality would extend to foreign policy issues as well, where both could cooperate better to face the rising power of China" (Chalmers 2020).

The approaches on China are substantially the same across the Atlantic. If we are to consider the Joint Communication of the European Parliament, the European Council and the Council, EU has establish, in March 2019, practically the same framework and demands, issues and problems identified (EU-China a Strategic Outlook 2019), in a less diplomatic format, in the 2019 report to the Congress of the US-China Economic and Security Review (2019 Report to the Congress of the USChina Economic and Security Review Commission 2019). Actually the concerns are the same: unfair practices, such as subsidising industries, stealing intellectual property, cyber-attacks and cyber espionage, keeping its currency low, coercing industries to transfer know how and putting up barriers to trade, genocide against the Uyghur population in the province of Xinjiang, attacking the autonomous democratic regime in Hong Kong via electoral and security laws, pressing Taiwan democracy and Tibet religious habitudes, extending territorial claims and unfriendly activities in South China Sea against its neighbours and limiting the freedom of navigation and flight in international waters and international airspace.

\section{THE COLD WAR CLICHÉ AND ITS LIMITS: POWER BALANCING AND PRIMACY OF COMPETITION}

There is very easy and superficial to resort to clichés such as the second Cold War or the third/fourth World War in describing the post-Covid-19 world order based on US-China relations. It is not the case and both references are wrong. In all aspects. And we have several arguments for that, the first and most important one is the degree of sophistication of the bilateral relations between China and the US and the triad already underlined before of the cooperation-competition-conflict in those relations. It doesn't mean it is easy to face the management of the right balance between the three tracks, in order to avoid the relationship not to sweep in uncharted territory of violence.

The differences of the competitors in the former US-USSR competition are enormous: theSoviet Union had a military and especially nuclear capability pair with the US, even though its economic capacity, at its peak, was less than $40 \%$ of that of America. China is matching the economic power, competing and getting to the same GDP in a decade, according to the estimates. China, on the contrary, does not match the military power of the US at a global level, but can challenge US in the regions and parts that are of essential interest. We could add the interdependence of both economies and the number of strategic common goals that US and China are sharing at the international level: nuclear non-proliferation, global heating and environment, if not also the need to avoid military confrontation and direct violence. This basis of common interests could help in finding ways to manage the strategic competition (Medeiros 2021).

The bilateral relationship benefits of a number of clichés, wide spread at the global level. First, the cliché of a rising China and a declining US(Marcus 2021). It is far from the truth, and the reference of the comparison of geopolitical power could show us the reality of a relationship where China was ranking the third after the US and the UK in 2019 (Roger 2019). "The West is inherently superior in the organisation of its politics, economy and society, while China is a bundle of malign contradictions" (Marcus 2021) is also a cliché and there are more and more analysts that think the opposite, remarking the adaptability of the one state-two system approach.

The great power competition in Asia and the strategy of the US to avoid that the region is dominated by a hostile hegemonic force(Bisley 2020) runs closer to the idea of power balancing or managing competition than blocking the development of China. We are moving closer to uncharted 
waters than to a Cold War or World War since the new US-China relationship seams to be more complex, harder to manage and most probable will last much longer.

Ian Bremmer has also approached and discussed the US-China relationship. China represents, therefore, a genuine threat to the US in terms of "short term geopolitical competition as well as long-term existential challenge" (Bremmer 2020). Bremmer also underlines the interdependence of the US and China and rejects the cliché of a Cold War 2.0. He listed as common interests, besides nuclear non-proliferation, climate change and pandemic, the macroeconomic stability, assuming that China will be a part of the solution.(Atlantic Council, in a study about the scenarios of the US under Biden administration, noted the possibility that China would not want the stability of the World, but will prefer taking advantage of the vulnerabilities, insecurities and instability of the economy, even on the future possible economic crisis (Burrows and Manning, 2021).

Bremmer also added that destroying China's economy means also destroying US economy as well (Bremmer 2020). We could add that we do not have the two blocks needed for a Cold War: if there is a possible block of democracies, the autocracies could not go together and make a block since all of them - China, Russia, Iran first and foremost - are dependent economically on the democratic countries and could not team up since their economies are not complementary. The real question mark stands behind the possibility of world to be polarized and the countries to be obliged to take parts.

On another point, it is still a question at what respect and how deep the integration of the EU countries are into the common effort required by Washington in order to counter China and support the new rules and norms needed at the level of the international system in relations with the new technologies. Mrs. Ursula von der Leyen already proposed the Transatlantic Technological Agreement to take the place of the rejected TTIP (Statement by President von der Leyen following her phone call with President of the United States 2021), and the project has already been embraced in the Congress, with the White House having this in mind for some time in its strategies - see the Interim National Security Strategic Guidelines(Biden, Jr. 2021-2) as well as the UK's Integrated Review of Security, Defense, Development and Foreign Policy, that has made the same point as a perspective for the UK until 2030 (Global Britain in a Competitive Age. Integrated Review on Security, Defense, Development and Foreign Policy 2021).

\section{ASSUMING RISKS, FRICTIONS, AVOIDING MILITARY CONFLICT AND CONFRONTATION}

The relation of the US and China has been already defined in a piece for Foreign Policy cosigned by Jake Sullivan, the new National Security advisor and Kurt Campbell, the new top Asia Adviser of the US President, in September 2019, under the concept of Competition Without Catastrophe (Campbell and Sullivan 2019), the way the US can both challenge and coexist with China. The paper noted that "the era of engagement with China has come to an unceremonious close". That would be the best definition of the bilateral relation today.

Fact is that the US has to accept more risks and the costs related to them in addressing China, coping with threats and challenges coming from China and confronting China on issues of first importance. Identifying, balancing, and managing risks is the solution (Medeiros 2021) of the real balance between the triad of cooperation, competition and confrontation with China, and America needs to learn to live with this new situation. It is a tremendous change in behaviour from a diplomatic form that requires, according to all the books, downplay disagreement, minimize friction, reduce competition, and expand cooperation. And to move to a type of risk management that involves assuming and tolerating risks, frictions, dealing with tensions, accepting a certain level of costs coming from those risks and using this new environment in the triad relation with China.

Yes, it is less acceptable and closer to an anti-fragile approach to foreign policy (Taleb 2014) the idea of balancing competing interests and avoid to always reconcile differences and disagreements. Some fundamental issues related to principles and values cannot be solved, but there's no need to try always to settle everything. Assuming the incompatible principles and valuesand the harsh competition is as important and hard as assuming depending from the other 
liberal democratic countries and a real multilateralism that has to accommodate common interests. Here the EU can play its part with the capacity of forging consensus with numerous actors as the idea of the legal power of the EU could be used by the US at a global stage through reforming the global institutions or introducing new ones with the new rules.

The strict combination of harsh competition, defend and deter military and strategic offensive moves towards allies and partners, democratic alliance as well as the system of international bounds via treaties and normative assumed commitments is a good step forward in dealing with China without any direct military confrontation, but with diplomacy and from the position of strength. The primacy of competition in U.S.-Chinese relations (Medeiros 2021) does not mean that military conflict or confrontation is inevitable, but the US needs to adapt in this coalition of democracies that it needs to forge and to lead. Power balancing, binding China in new normative and international institutions, degrade existing Chinese capabilities, international agreements and treaties that could pressure China into changing its behaviour, bilateral US-China competition, could represent the bases of a new American China policy.

At the same time, as Sullivan and Campbell underlined, competition without catastrophe means that any escalation of rivalry should avoid violence, military clashes of any kind and an acceptable level of risks and costs assumed (Sullivan and Campbell 2019). So, the competition between China and the US should be the new reality but the confrontation and conflictual part of the triad of relations should avoid spiraling out of control. It is about risk management but not competition limitations, military clashes denial but not lack of military show out, catastrophe avoidance but not refusing direct confrontation in defense of the principles and values. And using the military presence, development and deployments for defense and deterrence, when technological edge should ensure the dominant level of the combined democratic conglomerate, lead by the US, in order to enforce the rules based world.

\section{REFERENCES}

BBC. 2020. Coronavirus: Trump stands by China lab origin theory for virus 1 May. https://www.bbc.com/news/world-us-canada-52496098

BBC. 2020. US and China trade angry words at high-level Alaska talks. https://www.bbc.com/news/world-us-canada-56452471

Biden, Jr. Joseph R. 2021. Interim National Security Strategic Guidelines. file://C:/Users/ 23icc/Documents/Adevarul\%20blog/2021/martie/NSC-1v2\%20(1).pdf

Biden, Jr. Joseph R. 2021-1. Remarks by President Biden on America's Place in the World. U.S. Department of State Headquarters, Harry S. Truman Building Washington, D.C.https://www. whitehouse.gov/briefing-room/speeches-remarks/2021/02/04/remarks-by-president-biden-onamericas-place-in-the-world/

Biden, Jr. Joseph R. 2021-2. Interim National Security Strategic Guidelines. file://C:/Users/ 23icc/Documents/Adevarul\%20blog/2021/martie/NSC-1v2\%20(1).pdf

Bisley, Nick. 2020. The China-US rivalry is not a new Cold War. It is way more complex and could last much longer. The Conversation.https://theconversation.com/the-china-us-rivalry-is-not-a-newcold-war-it-is-way-more-complex-and-could-last-much-longer-144912

Bloomberg. 2020. Is it possible to end China's control of the global supply chain?. https://auto.economictimes.indiatimes.com/news/industry/is-it-possible-to-end-chinas-control-ofthe-global-supply-chain/76285274

Bremmer, lan. 2012. Every Nation for Itself. Winners and Loosers in a G0 World.Portfolio Penguin. 229.

Bremmer, Ian. 2020. No, the U.S. and China Are Not Heading Towards a New Cold War, Time. https://time.com/5920725/us-china-competition/ 
Burrows, Matthew and Manning Robert A. 2021. Three possible futures for the Biden presidency. New Atlanticist. https://www.atlanticcouncil.org/blogs/new-atlanticist/three-possible-futures-for-thebiden-presidency/

Bussiness Today. 2020. Japan's game plan - to pay companies to move out of China. https://www.businesstoday.in/current/world/japan-to-pay-companies-to-move-out-of-china-tocost-at-least-usd-536-million/story/410340.html\#: :text=Japan\%20is\%20planning\%20to\% 20pay,to\%20move\%20out\%20of\%20China.\&text=Japan\%20government\%20would\%20now\%2 Opay,in\%20other\%20Southeast\%20Asian\%20countries

Campbell, Kurt M. and Sullivan Jack. 2019. Competition without Catastrophe. How America can Both Challenge and Coexist with China. Foreign Affairs. https://www.foreignaffairs.com/ articles/china/competition-with-china-without-catastrophe

Chalmers, John. 2020. EU welcomes a "friend" in the White House, much to do together. Reuters, https://www.reuters.com/article/instant-article/idINKBN29P29I

Chifu, Iulian. 2020. „Noua geopolitică globală în era post-Covid-19”. Infosfera. Anul XII, nr.2/20201121.

Chifu, lulian. 2021-1. Ce nu spune discursul de politică externă al lui Joe Biden: utilizarea armatei, Irak, Iran, Afganistan şi Orientul Mijlociu. Adevărul.adev.ro/qo70qz

Chifu, Iulian. 2021-2. Coagularea democratică și europenizarea politicii americane: cele 8 priorități de politică externă pentru reașezarea lumii. Adevărul.https://adevarul.ro/international/stateleunite/coagularea-democratica-europenizarea-politicii-americane-cele-8-prioritati-politicaexterna-reasezarea-lumii-1_6045c3fd5163ec4271ae5280/index.html

Chifu, Iulian. 2021-3. Marea confruntare SUA - China: de la Asia de Sud-Est la Regiunea IndoPacific. Adevărul.https://adevarul.ro/international/in-lume/marea-confruntare-sua-china-asiasud-est-regiunea-indo-pacific-1_604ef45a5163ec4271e780c6/index.html

Chifu, Iulian. 2021-4. Refacerea relației SUA-UE: poziții comune pe Rusia, Estul Europei și Ucraina. Nuanțe față de „rivalul strategic” comun, China. Adevărul. https://adevarul.ro/ international/europa/refacerea-relatiei-sua-ue-pozitii-comune-rusia-estul-europei-ucrainanuante-fata-rivalul-strategic-comun-china-1_6047c7295163ec4271bbb92e/index.html

Collinson, Stephen. 2021. Insults fly as Biden locks horns with Russia and China. CNN. https://edition.cnn.com/2021/03/19/politics/president-joe-biden-russia-china/index.html

European Commission, High Representative of the Foreign Affairs and Security Policy, Joint Communication of the European Parliament, European Council and The Council. EU-China a Strategic Outlook, Strasbourg. 2019. https://ec.europa.eu/info/sites/info/files/communication-euchina-a-strategic-outlook.pdf

HM Government. 2021. Global Britain in a Competitive Age. Integrated Review on Security, Defense, Development and Foreign Policy.

Hui, Zhang, Yusha Zhao and Zhao Juechenng. 2021. Italy potentially had Covid-19 outbreak "earlier than Wuhan", study shows.Global Times. https://www.globaltimes.cn/content/1209646.shtml

Jacinto, Leela. 2020. Can the unmasking of China's Covid-19 'mask diplomacy' stem Beijing's global power grab? https://www.france24.com/en/20200501-can-the-unmasking-of-china-scovid-19-mask-diplomacy-stem-beijing-s-global-power-grab

Khan, Stephen. 2020. Donald Trump "Chinese virus": The politics of naming. The Conversation. https://theconversation.com/donald-trumps-chinese-virus-the-politics-of-naming-136796

Marcus, Jonathan. 2021. US-China relations: Beyond the 'Cold War' cliché. BBC. https://www.bbc.com/news/world-asia-56382793 
Mattis, James, Auslin Michael and Felter Joseph. 2020. Getting the Quad Right Is Biden's Most Important Job. The Quadrilateral Security Dialogue is the best hope for standing up to China. Foreign Policy.https://foreignpolicy.com/2021/03/10/getting-the-quad-right-is-bidens-mostimportant-job/

Medeiros, Evan. 2021. How to Craft a Durable China Strategy. Washington Must Reconcile Interdependence and Conflict.Foreign Affairs.https://www.foreignaffairs.com/articles/unitedstates/2021-03-17/how-craft-durable-china-strategy

Miller, Russell and Strashak William. 2021. China's Responsibility for Global Pandemic, Just Security. https://www.justsecurity.org/69398/chinas-responsibility-for-the-global-pandemic/.

Pamuk, Humeyra and Shalal Andrea. 2020. Trump administration pushing to rip global supply chains from China: officials. Reuters. https://www.reuters.com/article/us-health-coronavirus-usachina/trump-administration-pushing-to-rip-global-supply-chains-from-china-officialsidUKKBN22G0BZ

Readout of President Joseph R. Biden, Jr. Call with European Commission President Ursula von der Leyen. 2021. https://www.whitehouse.gov/briefing-room/statements-releases/2021/03/05/ readout-of-president-joseph-r-biden-jr-call-with-european-commission-president-ursula-von-derleyen/

Report to the Congress of the US-China Economic and Security Review Commission. 2019. https://www.uscc.gov/sites/default/files/2019-11/2019\%20Annual\%20Report\%20to\%20 Congress.pdf

Roger, James. 2019. Audit of Geopolitical Capability. An assessment of 20 major powers. Henry Jackson Society. https://henryjacksonsociety.org/wp-content/uploads/2019/01/HJS-2019-Auditof-Geopolitical-Capability-Report-web.pdf

Secretary of State Antony Blinken Speech on Foreign Policy Transcript. 2021. https://www.rev.com/ blog/transcripts/secretary-of-state-antony-blinken-speech-on-foreign-policy-transcript-march-3

Shumei, Leng and Lin Wan. 2020. US Urged to release health info of military athletes who came to Wuhan in October 2019.Global Times.https://www.globaltimes.cn/content/1183658.shtml

Small, Andrew. 2020. The meaning of systemic rivalry: Europe and China beyond the pandemic.ECFR.https://ecfr.eu/publication/the_meaning_of_systemic_rivalry_europe_and_chin a_beyond_the_pandemic/.I

Statement by President von der Leyen following her phone call with President of the United States, Joe Biden. 2021. https://ec.europa.eu/commission/presscorner/detail/en/statement_21_1048

Taleb, Nicholas Nassim. 2014. Antifragil. Editura Curtea Veche.

Terrabianca, Jose Ignacio. 2020. "Strength has to start at home": Interview with Borrell on the EU's response to the coronavirus.https://ecfr.eu/article/commentary_strength_has_to_start_ at_home_interview_with_borrell_on_the_eus/

Vilmer, Jean Baptiste Jeangene and CharonPaul. 2020. Russia as a hurricane, China as a climate change: different ways of information warfare.War on the Rocks.https://warontherocks.com/ 2020/01/russia-as-a-hurricane-china-as-climate-change-different-ways-of-information-warfare/.

Wiskeyman, Andrew and Berger Michael. 2021. Axis of Disinformation: Propaganda from Iran, Russia, and China on Covid-19.FIKRA Forum. https://www.washingtoninstitute.org/policyanalysis/axis-disinformation-propaganda-iran-russia-and-china-covid-19 